\title{
The Role of Magnesium in Neonatal Calcium Homeostasis: Effects of Magnesium Infusion on Calciotropic Hormones and Calcium
}

\author{
PHII.IP W. SHAUL, FRANCIS MIMOUNI, REgINALD C. TSANG. A.ND BONNY I. SPICKI:R \\ Department of Pediatrics. Division of Neonatologl: L'niversity of cincinnati college of Hedicine. \\ ('incinnati, Ohio 45267-()541
}

\begin{abstract}
ABSTRACI. Magnesium (Mg) deficiency is a possible etiologic factor contributing to neonatal hypocalcemia. In adults, parathyroid hormone ( $\mathrm{P}^{\prime} \mathrm{TH}$ ) secretion is negatively feedback regulated by acute changes in serum $\mathrm{Mg}$ concentration, but paradoxically Mg deficiency may lead to functional hypoparathyroidism and hypocalcemia. We hypothesized that in neonates, $\mathrm{Mg}$ administration will cause changes in P'III secretion and serum Ca concentration that will be inversely related to serum $\mathrm{Mg}$ status. We also hypothesized that $\mathrm{Mg}$ administration will result in increased calcitonin (CI) secretion. Thirty-nine newborn infants with birth weights $>1500 \mathrm{~g}$ were studied on day 3 of life. Ten received placebo, and 29 intravenous magnesium sulfate $\left(\mathrm{MgSO}_{4}\right), 6 \mathrm{mg}$ elemental $\mathrm{Mg} / \mathrm{kg}$ body weight, over $1 \mathrm{~h}$. Serum Mg, Ca, P'IH, and (CI were measured at time () (baseline, preinfusion) and 1,2,6,12,24, and $48 \mathrm{~h}$ postinfusion. In both groups combined, baseline PIII correlated with baseline $\mathrm{Mg}(r=0.72, p<0.005)$, and with baseline $\mathrm{Ca}(r=0.68, p<0.005)$. In the control group there was no change in serum $\mathrm{Mg}$, Ca, Plll, and CI during the study period. In magnesium sulfate-infused infants: 1 ) serum Mg concentration rose from $1.80 \pm 0.06$ to $2.82 \pm 0.07 \mathrm{mg} / \mathrm{dl}($ mean $\pm S F M, p<0.001) ; 2$ ) the change from baseline in serum $\mathrm{P}^{\prime} \mathrm{l} H \mathrm{I}$ at 1,6 , and $12 \mathrm{~h}$ postinfusion correlated inversely with baseline $\operatorname{Mg}(p<0.05) ; 3)$ the change from baseline in serum $\mathrm{Ca}$ at 1,2 , and $24 \mathrm{~h}$ postinfusion correlated inversely with baseline $\mathrm{Mg}(p<$ $0.005)$; 4) serum (I remained unchanged. We conclude that Mg plays an important role in neonatal calcium metabolism. P'III and (a responses to magnesium sulfate infusion were inversely related to neonatal serum $\mathrm{Mg}$ concentrations, consistent with the hypothesis tested. $11 \mathrm{~g}$ infusion, however, did not affect neonatal serum ("I concentrations. (Pediatr Res 22: 319-323, 1987)
\end{abstract}

Abbreviations

PIII, parathyroid hormone

$\mathrm{Mg}$, magnesium

(a, calcium

MgS(O), magnesium sulfate

(CI, calcitonin

Received September \&. 1986: accepted April 1.t. 1987

(omespondence and reprint requests I. Mimouni. M.I).. I)epartment of Pediatrics. Aniversity of ( incinnati ( onlege of Medicine. 231 Bethesda Avenue. ("incinnati. ()his) $45267-(0,541$.

Supported in part by lesplas traming in perinatal (atre and Rescarch (iram

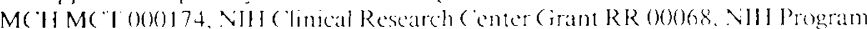
Projecl (irant HI) 11725 . Nill Perinatal tomphasis Research (inter 111 ) 20748. and the (hildren's Hespital Rescarch foundation.
Hypocalcemia is a frequently encountered problem in the neonatal period (1-7). Magnesium deficiency and transient hypoparathyroidism are two etiologic factors that have been implicated in this disorder. These two etiologic factors maly be interrelated. In Mg-replete adults. PTH secretion is negatively feedback regulated by acute changes in serum Mg concentration ( 8 . 9). Acute decreases in serum $\mathrm{Mg}$ concentration stimulate P'TH secretion, and acute increases in serum Mg reduce P'Tll secretion. However, paradoxically $\mathrm{Mg}$ deficiency in adults suppresses PTH secretion by affecting the Ca-sensitive. Mg-dependent adenylate cyclase system or other Ca-mediated mechanisms of P'III secretion. In this instance the infusion of $\mathrm{Mg}$ has been associated with increases in serum PTH concentration (10).

A third etiologic factor that may contribute to the pathogenesis of neonatal hypocaleemia involves neonatal ("l production. Serum CT concentrations have been found to be relatively elevated at birth. with further increases in the immediate postnatal period (11. 12). It has been suggested that an elevated serum CI concentration in the neonate may be physiologic. protecting the skeleton from excessive hone resorption, and protecting the newborn from acute hypercaleemia during milk feedings. However, elevated ("I theoretically may also contribute to the neonatal tendency for hypocalcemia (13). It has been found that neonatal ("I secretion increases when (at is administered (12.14). The effect of $\mathrm{Mg}$ administration on ("I secretion in the neonate has not been previously investigated.

The present study was conducted to further our understanding of the role of $\mathrm{Mg}$ in neonatal (a homeostasis by examining the effects of $\mathrm{Mg}$ infusion on P'TH and ("T secretion. and serum (a concentration. We hypothesized that in neonates. Mg administration will cause changes in PTH secretion and serum (a concentration that will be inversely related to serum Me status. Infants with lower initial serum Mg concentrations will respond with increased PTH secretion and increased serum (a concentrations. while those with higher initial serum Mg concentrations will respond with decreased PTH secretion and decreased scrum (a concentrations. We also hypothesized that the effect of $\mathrm{Mg}$ on ('T secretion is similar to the effect of (a. such that Mg administration results in an increase in ("I secretion.

\section{MFTHODS}

Thirty-nine newborn infants in the veonatal Intensive (are Unit at the University of (incinnati Medical (enter or at the (hildren's Hospital Medical (enter between 1982 and 1984 were enrolled in the study by the second day of life. Infants chosen for study had birth weights of more than 150() g. and had intravenous access for clinical indications. By study design there were infants enrolled who were at low risk for hypomagnesemia. as well as infants in high risk categories. such as infants of diabetic mothers (17). small for gestational age infants (17), and birtbasphyxiated infants (18). 
To avoid the risks of hypermagnesemia during the study we excluded infants born to mothers who received $\mathrm{MgSO}_{4}$ prior to delivery for the treatment of preeclampsia or for tocolysis $(19$, 20). We also excluded infants with possible impairment in renal function on the day of study since $\mathrm{Mg}$ is primarily excreted by the kidney. Impaired renal function was determined by any of the following criteria: blood urea nitrogen concentration greater than $15 \mathrm{mg} / \mathrm{dl}$, serum creatinine concentration greater than 1.2 $\mathrm{mg} / \mathrm{dl}$, or urine output less than $1.0 \mathrm{ml} / \mathrm{kg}$ body weight $/ \mathrm{h}$. Infants with serum $\mathrm{Mg}$ concentration of more than $2.5 \mathrm{mg} / \mathrm{dl}$ on day 1 or 2 of life were also excluded. By study design it was decided that hypocalcemia (serum total $\mathrm{Ca}$ concentration $<7 \mathrm{mg} / \mathrm{dl}$ ) would not be treated with Ca salts unless the infant was symptomatic, or the serum total $\mathrm{Ca}$ concentration was $<6 \mathrm{mg} / \mathrm{dl}$. None of the enrolled infants fulfilled those criteria and none received calcium supplementation prior to or during the study period.

The study was approved by the University of Cincinnati Human Research Committee and written informed parental consent was obtained at the time of enrollment.

The first 20 infants studied all received a $\mathrm{MgSO}_{4}$ infusion. It was then decided that examination of $\mathrm{Mg}$-induced changes in $\mathrm{Ca}$ metabolism by comparison to baseline measurements was insufficient, and a control group receiving a placebo infusion was formed. The subsequent patients enrolled were randomized to either $\mathrm{MgSO}_{4}$ or placebo infusion in a double-blinded manner. The final study and control groups consisted of 29 and 10 infants, respectively. Since there were no differences between the earlier and later $\mathrm{MgSO}_{4}$-infused infant groups, these are presented as a single $\mathrm{MgSO}_{4}$ infusion group.

The study was performed at $72 \pm 12 \mathrm{~h}$ of age. Infants who were on oral feedings were given nothing by mouth for $4 \mathrm{~h}$ prior to the infusion. Intravenous fluids were administered from $2 \mathrm{~h}$ preinfusion to $2 \mathrm{~h}$ postinfusion with the rate and composition determined by the physicians caring for the infant. The fluid rate was based on the patient's weight and postnatal age and it ranged from 80 to $110 \mathrm{ml} / \mathrm{kg} /$ day. Electrolytes added to the fluids included $\mathrm{NaCl}, 2$ to $3 \mathrm{mEq} / \mathrm{kg} /$ day, and $\mathrm{KCl}, 1$ to $2 \mathrm{mEq} / \mathrm{kg} /$ day. Feedings were resumed $2 \mathrm{~h}$ postinfusion. Infants who were exclusively on intravenous fluids prior to the onset of the study remained on those fluids during the study period.

The infants who received the $\mathrm{MgSO}_{4}$ infusion were given 6.0 $\mathrm{mg}$ elemental $\mathrm{Mg} / \mathrm{kg}$ body weight as $5 \% \mathrm{MgSO}_{4} 7 \mathrm{H}_{2} \mathrm{O}, 1.2 \mathrm{ml} /$ $\mathrm{kg}$, added to the intravenous fluids for $1 \mathrm{~h}$. This $\mathrm{Mg}$ dose is equal to an infant's approximate daily requirement of $\mathrm{Mg}$ and to the recommended dose of $\mathrm{Mg}$ for the acute treatment of hypomagnesemia (15). It is also a dose that we expected to keep the serum $\mathrm{Mg}$ concentration within normal range. The control infants received a placebo infusion of an equal volume of $\mathrm{D}_{5} \mathrm{~W}$ added to the intravenous fluids for $1 \mathrm{~h}$. The $5 \% \mathrm{MgSO}_{4} 7 \mathrm{H}_{2} \mathrm{O}$ and $\mathrm{D}_{5} \mathrm{~W}$ vials were prepared, coded, and randomized by the Children's Hospital pharmacy. Serum $\mathrm{Mg}, \mathrm{Ca}, \mathrm{PTH}$, and CT concentrations were measured preinfusion at time 0 (baseline) and at $1,2,6,12,24$, and $48 \mathrm{~h}$ postinfusion. The volumes of blood sampled were in accordance with University of Cincinnati Human Research Committee guidelines, which stipulate that the total amount of blood drawn must be less than $5 \%$ of blood volume. When the size of an infant limited blood sampling, the priority specimens obtained were usually at 0,1 , and $6 \mathrm{~h}$ postinfusion.

During the infusion period the heart rate and respiratory rate were determined continuously and blood pressure was measured every $15 \mathrm{~min}$. These precautions were taken to detect the development of respiratory depression or hypotension, which are theoretically possible complications of a $\mathrm{Mg}$ infusion $(21-24)$. Side effects were not observed in any infant.

Serum $\mathrm{Ca}$ and $\mathrm{Mg}$ concentrations were measured by atomic absorption spectrophotometry (25). Serum PTH concentration was determined as outlined by Arnaud et al. (26), with modifications that have been previously described (6). Antiserum was produced in guinea pigs in response to injection with partially purified bovine PTH. The antibody produced detects 1-84 PTH (27). Plasma obtained from chronic hemodialysis patients was employed as the standard. ${ }^{125}$ I-labeled highly-purified bovine PTH was used in the radioimmunoassay. The normal adult range is $33-117 \mu \mathrm{l} \mathrm{Eq} / \mathrm{ml}$, with intraassay and interassay coefficients of variation of 8 and $15 \%$, respectively. Serum CT concentration was measured by a modification of the radioimmunoassay procedure described by Heath and Sizemore (14, 28). Normal adult values are less than $107 \mathrm{pg} / \mathrm{ml}$, with intraassay and interassay coefficients of variation of 6 and $15 \%$, respectively.

Statistical analysis was performed using repeated measures analysis, analysis of variance, and linear regression methods for continuous data. Discrete data were analyzed by the $\chi^{2}$ test. When the number of patients in any of the cells was less than 5 , the Fisher-exact test was employed. The BMDP statistical package was utilized for repeated measurement analyses (29), and the SAS package for analysis of variance and linear regression (30). Results are expressed as mean \pm SEM. A $p$ value of $<0.05$ is considered significant.

\section{RESULTS}

The clinical characteristics of the infants studied are depicted in Table 1. Gestational age, as determined by history from the mother's last menstrual period, and birth weight were similar for the two groups. The number of infants who were small for gestational age (birth weight less than the 10th percentile for gestational age), large for gestational age (birth weight greater than the 90th percentile for gestational age), and appropriate for gestational age (birth weight between the 10th and 90th percentile for gestational age) (31) were also similar for the two groups. The rate of birth asphyxia, defined by a 1-min Apgar score less than 7 , and the number of infants born to mothers with insulindependent diabetes also did not differ between the groups.

Serum $\mathrm{Mg}$ concentrations for both groups are shown in Table 2. Baseline serum $\mathrm{Mg}$ was similar for the two groups. In the study group the serum $\mathrm{Mg}$ increased from $1.80 \pm 0.06$ to $2.82 \pm$ $0.07 \mathrm{mg} / \mathrm{dl}(p<0.001)$ by the end of the $\mathrm{MgSO}_{4}$ infusion, and it then slowly declined back to baseline by $48 \mathrm{~h}$ postinfusion. In the control group there was no change in serum $\mathrm{Mg}$ concentration throughout the study period.

Baseline serum PTH concentrations were similar for the control and $\mathrm{MgSO}_{4}$ infusion groups (Table 3). The two groups were therefore pooled together to examine the relationships between baseline serum PTH concentrations and serum $\mathrm{Mg}$ and $\mathrm{Ca}$ concentrations. Baseline PTH correlated with baseline $\mathrm{Mg}(r=$ $0.72, p<0.005)$ and with baseline $\mathrm{Ca}(r=0.68, p<0.005)$. Examination of Table 3 reveals that there was no change in mean serum PTH concentration during the study period in either the control or $\mathrm{MgSO}_{4}$ infusion groups. However, in the $\mathrm{MgSO}_{4}$ infusion group the absolute change from baseline in serum PTH

Table 1. Clinical characteristics of infants studied*

\begin{tabular}{ccc}
\hline & $\begin{array}{c}\text { Control } \\
(n=10)\end{array}$ & $\begin{array}{c}\mathrm{MgSO}_{4} \text { infusion } \\
(n=29)\end{array}$ \\
\hline Gestational age (wk) & & \\
Mean \pm SEM & $35.2 \pm 0.8$ & $35.6 \pm 0.6$ \\
Birth weight $(\mathrm{kg})$ & & \\
Mean \pm SEM & $2.43 \pm 0.22$ & $2.57 \pm 0.24$ \\
SGA $n(\%)$ & $2(20)$ & $5(17)$ \\
AGA $n(\%)$ & $7(70)$ & $21(72)$ \\
LGA $n(\%)$ & $1(10)$ & $3(10)$ \\
Birth asphyxia & & \\
$n(\%)$ & $5(50)$ & $15(52)$ \\
IDMs $n(\%)$ & $1(10)$ & $2(7)$ \\
\hline
\end{tabular}

* SGA, small for gestational age; AGA, appropriate for gestational age; LGA, large for gestational age; IDMs, infants of diabetic mothers. 
Table 2. Serum Hy and ca comecntrations in comtrol and Mg.SO) infusion group. *

\begin{tabular}{|c|c|c|c|c|}
\hline \multirow{2}{*}{$\begin{array}{l}\text { Time } \\
\text { postinfusion } \\
\text { (h) }\end{array}$} & \multicolumn{2}{|c|}{$\mathrm{Mg}(\mathrm{mg} / \mathrm{dl})$} & \multicolumn{2}{|c|}{$(\mathrm{a}(\mathrm{mg} / \mathrm{dl})$} \\
\hline & $\left.\left(\operatorname{con} t \mathrm{r}^{\circ}\right)\right]$ & $\mathrm{MgSO})_{4}$ & control & $\mathrm{MgSO}_{4}$ \\
\hline Baselinc & $\begin{array}{c}1.89 \pm 0.06 \\
(10)\end{array}$ & $\begin{array}{c}1.80 \pm 0.06 \\
(20)\end{array}$ & $\begin{array}{c}8.01 \pm 0.15 \\
(10)\end{array}$ & $\begin{array}{c}7.89 \pm 0.19 \\
(29)\end{array}$ \\
\hline 1 & $\begin{array}{c}1.84 \pm(1.04 \\
(10)\end{array}$ & $\begin{array}{c}2.82 \pm 0.07+ \\
(29)\end{array}$ & $8.06 \pm 0.15$ & $\begin{array}{c}7.91 \pm(0.19 \\
(29)\end{array}$ \\
\hline 2 & $\begin{array}{c}1.82+0.07 \\
(5)\end{array}$ & $\begin{array}{c}2.62 \pm 0.06 \% \\
(16)\end{array}$ & $\frac{8.23 \pm(0.30}{(5)}$ & $\begin{array}{c}7.89 \pm 0.23 \\
(16)\end{array}$ \\
\hline 6 & $\begin{array}{c}1.88 \pm 0.07 \\
(10)\end{array}$ & $\begin{array}{c}2.45 \pm 0.06 \% \\
(27)\end{array}$ & $\begin{array}{c}8.23 \pm(0 . .30) \\
(10)\end{array}$ & $\begin{array}{c}7.93 \pm 0.16 \\
(27)\end{array}$ \\
\hline 12 & $\begin{array}{c}1.88 \pm 0.04 \\
(4)\end{array}$ & $\begin{array}{c}2.55 \pm 0.14 \% \\
(12)\end{array}$ & $\begin{array}{c}7.86 \pm(0.12 \\
(3)\end{array}$ & $\begin{array}{c}8.01 \pm 0.28 \\
(11)\end{array}$ \\
\hline 24 & $1.90 \frac{ \pm 0}{(9)}$ & $\begin{array}{c}2.18 \pm 0.07+ \\
(26)\end{array}$ & $\begin{array}{c}8.64 \pm 0.24 \\
\text { (9) }\end{array}$ & $\begin{array}{c}8.30 \pm 0.16 \\
(26)\end{array}$ \\
\hline 48 & $\begin{array}{c}1.95 \pm 0.07 \\
(9)\end{array}$ & $\begin{array}{c}2.08 \pm 0.07 \\
(2.3)\end{array}$ & $8.96 \pm 0.18$ & $8.55 \pm 0.16$ \\
\hline
\end{tabular}

* Values represent means \pm SI:M: values in parentheses represent the number of subjects.

$+p<0.05$ compared to haseline and to control group.

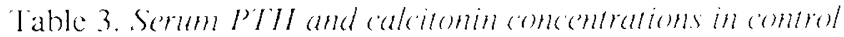
and 1/g.SO) infusion groups. ${ }^{*}$

\begin{tabular}{|c|c|c|c|c|}
\hline \multirow{2}{*}{$\begin{array}{l}\text { Time } \\
\text { postinfusion } \\
\text { (h) }\end{array}$} & \multicolumn{2}{|c|}{$\operatorname{PIH}(\mu] \mathrm{I}(\mathrm{l} / \mathrm{ml})$} & \multicolumn{2}{|c|}{ ("l' (ng/ml) } \\
\hline & Control & $\mathrm{MgSO})_{4}$ & Control & $\mathrm{MgSO}_{4}$ \\
\hline Baseline & $30.4 \pm 5.5$ & $\begin{array}{c}34.5 \pm 3.8 \\
(24)\end{array}$ & $\begin{array}{c}123 \pm 20 \\
(9)\end{array}$ & $\begin{array}{c}224 \pm 67 \\
(25)\end{array}$ \\
\hline 1 & $\begin{array}{c}27.4 \pm 5.8 \\
(7)\end{array}$ & $\begin{array}{c}32.0 \pm 2.6 \\
(27)\end{array}$ & $\begin{array}{c}100 \pm 14 \\
(7)\end{array}$ & $\begin{array}{c}254 \pm 105 \\
(22)\end{array}$ \\
\hline 2 & $\begin{array}{c}25.0 \pm 2.3 \\
(3)\end{array}$ & $\begin{array}{c}27.9 \pm 3.1 \\
(14)\end{array}$ & $\begin{array}{c}93 \pm 22 \\
(4)\end{array}$ & $\begin{array}{c}298 \pm 197 \\
(13)\end{array}$ \\
\hline 6 & $\begin{array}{c}31.5 \pm 5.7 \\
(8)\end{array}$ & $\begin{array}{c}29.4 \pm 2.8 \\
(2.3)\end{array}$ & $\begin{array}{c}y() \pm 13 \\
(9)\end{array}$ & $\begin{array}{c}192 \pm 62 \\
(20)\end{array}$ \\
\hline 12 & $\begin{array}{c}29.0 \pm 6.1 \\
(3)\end{array}$ & $\begin{array}{c}30.7 \pm 5.7 \\
(10)\end{array}$ & $\begin{array}{c}4() \pm 9 \\
(3)\end{array}$ & $\begin{array}{c}140 \pm 5 \\
(7)\end{array}$ \\
\hline 24 & $\begin{array}{c}30.5 \pm 6.9 \\
(6)\end{array}$ & $\begin{array}{c}3(1.5 \pm 3.2 \\
(25)\end{array}$ & $\begin{array}{c}78 \pm 16 \\
(7)\end{array}$ & $\begin{array}{l}99 \pm 16 \\
(22)\end{array}$ \\
\hline 48 & $\begin{array}{c}35.0 \pm .5 .6 \\
(7)\end{array}$ & $\begin{array}{c}34.5 \pm 4.7 \\
(16)\end{array}$ & $\begin{array}{c}79 \pm 22 \\
(8)\end{array}$ & $\begin{array}{c}70 \pm 8 \\
(17)\end{array}$ \\
\hline
\end{tabular}

* Values represent mean \pm SI:M: values in parentheses represent the number of subjects. concentration in individual subjects correlated inversely with baseline serum Mgconcentration when Pllt was measured at 1 $\mathrm{h}(r=0.64 ., p<0.001)$. at $6 \mathrm{~h}(r=-0.49 . r)<0.05)$. and at 12 $h$ postinfusion $(r=-0.62 . p=<(0.05)$. Figure 1 depicts this relationship at $1-h$ postinfusion.

Serum (a concentrations for both groups are shown in Table 2. Baseline serum (a was similar for the two groups. and there was no change in mean serum (a during the study period in either the control or $\mathrm{MgSO}$, infusion groups. Howcer. examination of the responses of individual subjects revals that there was a relationship between the baseline serum Mg concentration and the absolute change in serum (a concentration in response to $\mathrm{MgSO}_{4}$ infusion. The absolute change from baseline in serum (a concentration correlated inversely with baseline serum Mg concentration when (a was measured at $1 \mathrm{~h}(r--0.56 .1)<$

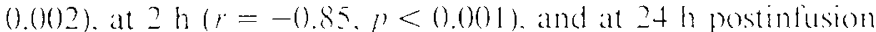
$(r=-0.54 . p<0.0(05)$. Figure 2 depicts this relationship at $2 h$ postinfusion

In both groups there was great variability in serum ("I concentrations (Table 3). Bascline serum ("I concentrations were similar. Pooling of baseline data from the two groups revealed no relationship between baseline serum Mg or (a concentration and baseline serum ("I concentration. In both the control and $\mathrm{MgS(})_{4}$ infusion groups there was a trend of dectining mean serum ("I" concentrations over the study period which did not reach statistical significance. Vo retationship was found between changes in serum (" I concentration following Mg infusion and baseline serum Mg concentration.

\section{1)IS( 1 :SSIO)}

The population studied included infants who were preterm as well as term. small for gestational age and large for gestational age as well as appropriate for gestational age infants. and infants who were at high risk for hypomagnesemia or hypocaleemia as well as those who were at low risk for those conditions 17. 17. 18). Such a varied population was chosen to theoretically provide a group of infants who would have Mg status ranging from "depleted" to "normal." Many more infants would be required 10 examine the specific effects of rariables such as gestational age, intraterine growth retardation. maternal diabetes. or perinatal asphexia on the P'IH or ("I response to MgSO), aldministration.

The serum $\mathrm{Mg}$ concentration following the $\mathrm{MgSO}$. infusion remained within or close to the normal range for neonates, which is 1.5 to $2.8 \mathrm{mg} / \mathrm{dl}(15-17)$. This permitted the evaluation of the

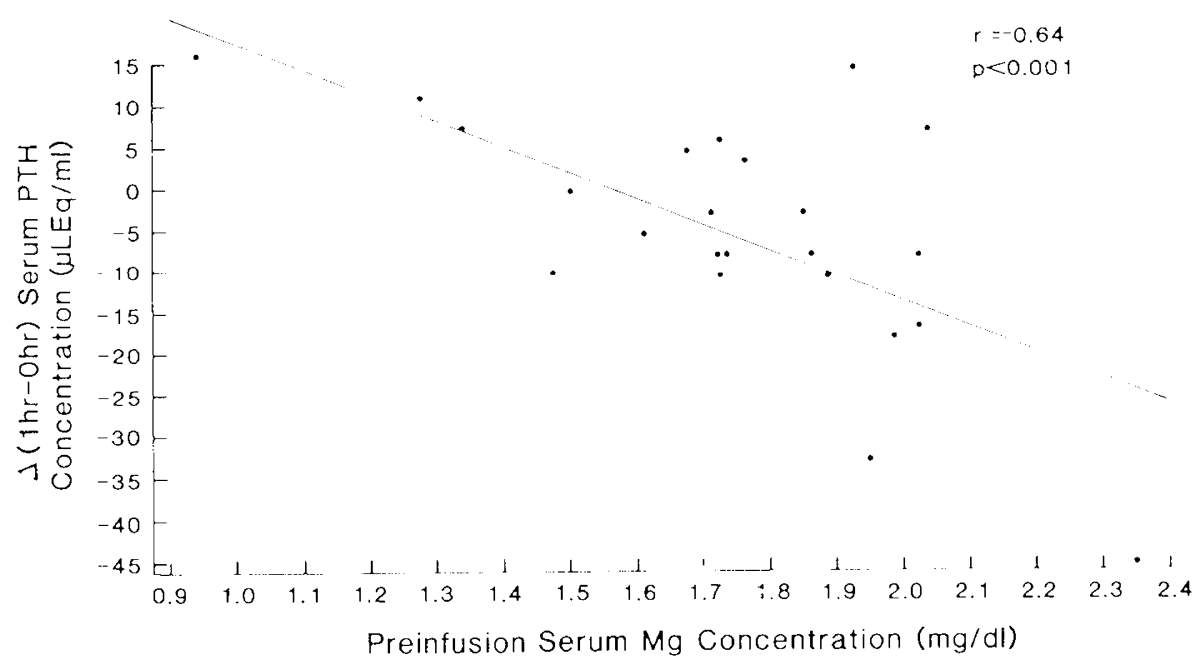

Fig. 1. Relationship between preinfusion serum $\mathrm{Mg}$ concentration and the change in serum PTH concentration from basejine to $1 \mathrm{~h}$ post-Mgs(), infusion [د PTH (l-() h)]. 


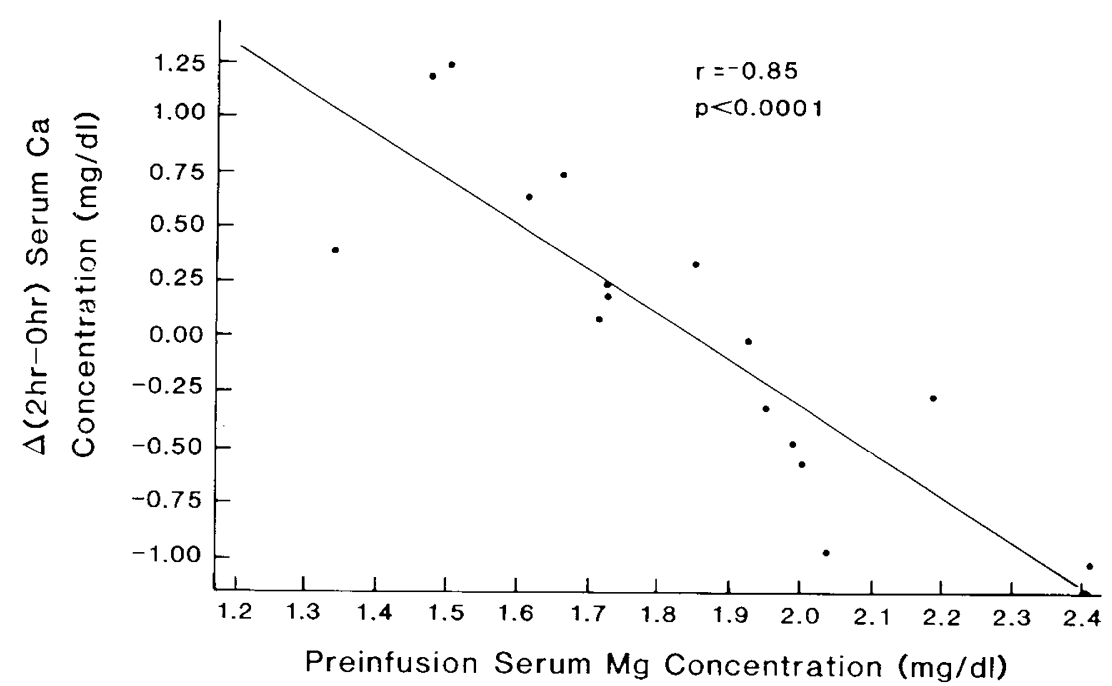

Fig. 2. Relationship between preinfusion serum $\mathrm{Mg}$ concentration and the change in serum calcium concentration from baseline to $2 \mathrm{~h}$ post$\mathrm{MgSO}_{4}$ infusion $[\Delta \mathrm{Ca}(2-0 \mathrm{~h})]$.

effects of $\mathrm{Mg}$ on PTH and CT secretion in ranges of serum $\mathrm{Mg}$ concentration that were close to probable "physiologic" concentrations as opposed to "pharmacologic" ones. In the present study the serum $\mathrm{Mg}$ concentration has been treated as a continuous variable. The infants were not placed into hypomagnesemia versus normomagnesemia groups because serum $\mathrm{Mg}$ concentration generally has been considered to be a "poor" index of tissue $\mathrm{Mg}$ status; $\mathrm{Mg}$ is mainly an intracellular ion (33). When serum $\mathrm{Mg}$ concentrations are reduced, tissue $\mathrm{Mg}$ stores indeed may have been depleted; but in the normal ranges of serum $\mathrm{Mg}$ concentrations it has been difficult to assess tissue $\mathrm{Mg}$ status. Apparently, reduced tissue $\mathrm{Mg}$ stores can be associated with normal serum $\mathrm{Mg}$ concentrations $(34,35)$. The relationship between tissue $\mathrm{Mg}$ status and serum $\mathrm{Mg}$ concentration in the newborn human or animal remains unclear.

The present findings support the hypothesis that the PTH response to $\mathrm{Mg}$ administration is inversely related to initial serum $\mathrm{Mg}$ status. The linear regression analyses of the baseline $\mathrm{Mg}, \mathrm{Ca}$, and PTH data demonstrate the close relationships that exist among serum $\mathrm{Mg}$, serum $\mathrm{Ca}$, and serum PTH concentrations in the neonatal period. The role of $\mathrm{Mg}$ in neonatal parathyroid gland function is not evident, however, until one examines the influence of baseline $\mathrm{Mg}$ status on the parathyroid response to $\mathrm{Mg}$ infusion. The change in serum PTH concentration following $\mathrm{MgSO}_{4}$ administration was inversely related to the baseline serum $\mathrm{Mg}$ concentration. Infants with a comparatively low initial serum $\mathrm{Mg}$ concentration responded to $\mathrm{Mg}$ infusion with an increase in serum PTH concentration, while infants with a comparatively high initial serum $\mathrm{Mg}$ concentration had a decrease in serum PTH concentration postinfusion.

Two previous studies have indirectly examined the neonatal parathyroid response to $\mathrm{Mg}$ administration. Donovan et al. (19) studied the effect of maternally administered $\mathrm{MgSO}_{4}$ on neonatal serum PTH concentrations during the first 3 days of life. The mean serum $\mathrm{Mg}$ concentration was $4.8 \mathrm{mg} / \mathrm{dl}$ in cord blood samples and it remained above $3.0 \mathrm{mg} / \mathrm{dl}$ for the following 3 days. Throughout the study period the serum PTH concentration was decreased compared to control infants (18). In a similar study Cruikshank et al. (20) also found that infants born to $\mathrm{MgSO}_{4}$-treated mothers had decreased serum PTH concentrations in cord blood compared to controls. In contrast to the present study, the neonates in both these reports were overtly hypermagnesemic and their baseline $\mathrm{Mg}$ status prior to maternal $\mathrm{MgSO}_{4}$ infusion was unknown.

Rude et al. (32) compared the PTH response to Mg administration in Mg-deficient and normal adult subjects. The Mgdeficient adult patients responded with an increase in serum PTH concentration while normal adults had a decrease or little change in the serum PTH concentration. Thus, the response we found in infants with low serum $\mathrm{Mg}$ concentrations resembles that of $\mathrm{Mg}$-deficient adults, and the response in neonates with higher serum $\mathrm{Mg}$ concentrations resembles that of normal adults.

The serum $\mathrm{Ca}$ response to $\mathrm{MgSO}_{4}$ infusion was similar to the PTH response in that it also was inversely related to the baseline serum $\mathrm{Mg}$ concentration. Infants with a comparatively low initial serum $\mathrm{Mg}$ concentration responded to the infusion with an increase in serum $\mathrm{Ca}$ concentration, while infants with a comparatively high initial serum $\mathrm{Mg}$ concentration had a decrease in serum $\mathrm{Ca}$ concentration postinfusion. The observed changes in serum $\mathrm{Ca}$ concentration could be in part due to the effects of $\mathrm{MgSO}_{4}$ administration on PTH secretion, since changes in serum PTH affect directly and positively the serum $\mathrm{Ca}$ concentration. There were infants, however, who responded to the $\mathrm{MgSO}_{4}$ infusion with increases in serum $\mathrm{Ca}$ concentration who did not have measurable increases in serum PTH concentration. For example, at $2 \mathrm{~h}$ postinfusion seven of 10 infants who had increased serum $\mathrm{Ca}$ compared to baseline did not have an associated increase in serum PTH concentration. A possible explanation is that $\mathrm{Mg}$ administration in these infants resulted in increased exchange of $\mathrm{Mg}$ for $\mathrm{Ca}$ at the bone surface, shifting Ca from bone to the extracellular space, with a subsequent increase in serum $\mathrm{Ca}$ concentration (36). Such a mechanism may account for the observed increase in serum $\mathrm{Ca}$ concentration despite decreased serum PTH concentration in the previous cited study of neonatal hypermagnesemia by Donovan et al. (19).

There was no change in serum $\mathrm{CT}$ concentration in response to $\mathrm{MgSO}_{4}$ administration. In a previous study of the effects of maternal $\mathrm{MgSO}_{4}$ treatment on perinatal $\mathrm{Ca}$ metabolism, cord blood $\mathrm{CT}$ concentrations in Mg-treated neonates did not differ from controls (19). In the present study, the trend of declining serum CT concentrations over the study period is consistent with the results obtained in investigations of the CT status of infants during the first $2 \mathrm{wk}$ of life $(14,37)$.

In summary, $\mathrm{Mg}$ infusion in the neonatal period resulted in changes in serum PTH and Ca concentrations that were inversely related to the baseline serum $\mathrm{Mg}$ concentration, consistent with the hypothesis tested. Elevation of serum Ca concentration following $\mathrm{Mg}$ administration may be due to increased PTH secretion and/or increased exchange of $\mathrm{Mg}$ for $\mathrm{Ca}$ at bone surfaces. CT secretion was not affected by $\mathrm{Mg}$ administration. $\mathrm{Mg}$ status appears to exert important effects on neonatal Ca homeostasis.

\section{REFERENCES}

1. Tsang RC, Oh W 1970 Neonatal hypocalcemia in low birth weight infants.
Pediatrics $45: 773-781$ 2. Tsang RC. Light IJ, Sutherland JM, Kleinman LI 1973 Possible pathogenetic 


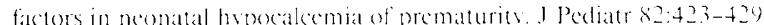

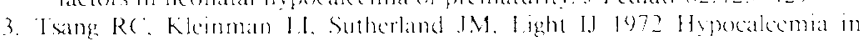
inlants of diabetic mothers I Pedtate 80.384 .395

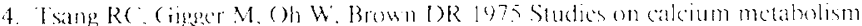

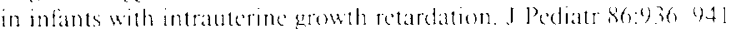

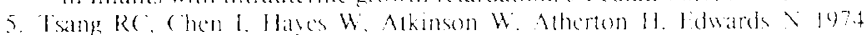

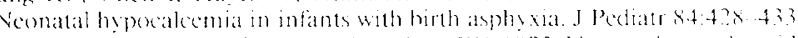

6. Isang Re (hen IW. Iriedman MS. Chen IW 1973 Veonatal parathroid function: role of gestational age and postmatal age J Pediate \&3.7.

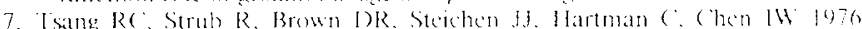
Hypomagnescmia in infants of dabetic mothers: perinatal studies I lediatr $80: 115.110$

8. Buckle RM. (ate AI). (onper ( W 1968 the influence of plasma magnesium

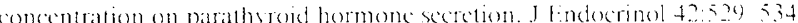

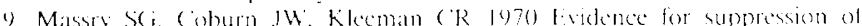
parathroid gland activity by hypermagnesemia. J (lin invest 49:1619) 1629)

10. 1evine BS. Coburn IW 1984 Magnesium, the mimic/antagonist of calcium $V$ Inn:l J Med 310:125331255

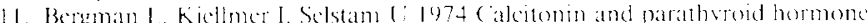
relation to earle neonatal hepocalcemia in infants of diabetic mothers. Biol Ne(onate $24: 151 \cdot 157$

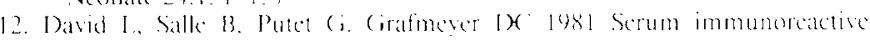
calcitonin in low hirth weight infants: description of early changes: effect of intravenous cakcium infusion: relationships with carls changes in serum calcium. phospherus. magnesium. paratheroid hormone and gastrin levels. Pediatr Res 15.803 .808

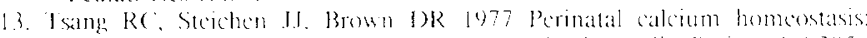
neonatal hepocalcemia and bore demineralization. (Clin Perinated 4:385 $4(1)$

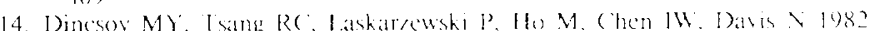
Serum calcitonin response 10 adminsstration of calcium in ncuborn infants during exchange hloged transfusion. J Pediate $100: 78$ ? -2.80

15. Mimounit. Tsang R( 1986 D dsorders of calcium and magnesium metabolism.

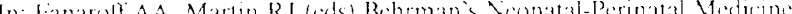

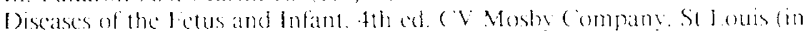
(uress)

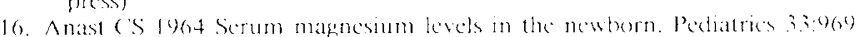
974

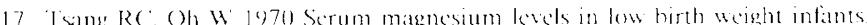

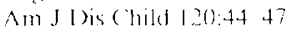

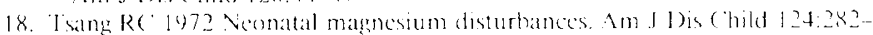
20) 3

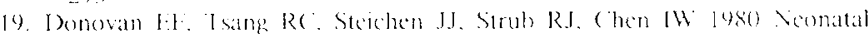

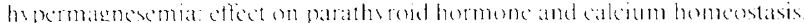

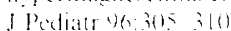

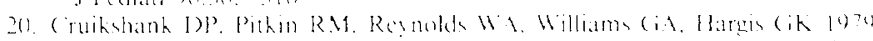

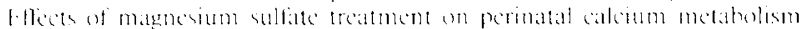

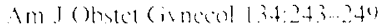

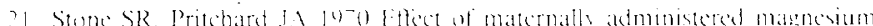

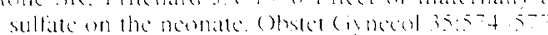

2. lipsit PJ. Ingtigh IC log Hupermagnesemia in the newhorn infant. Pediat

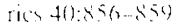

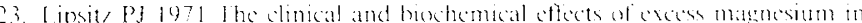
the nowborn. Pediatries $t^{-}=801$ som

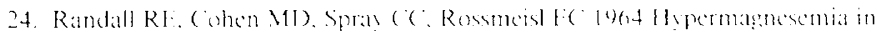
renal failure. ctologes and toxic mantestations Ann Intern Med $61:=77$

25 Sunderman IW. (arroll fl 1905 Measurements of serum calcium and matr-

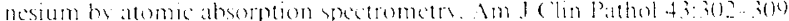

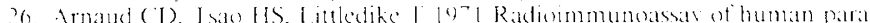
thyroid hormone in serum. I ( lin lnsest $50: 21$ ? ?

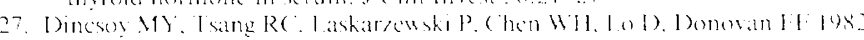

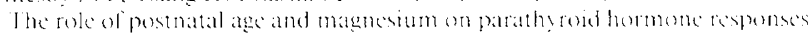
during "exchange" blowel transtusion in the newhorn period. I l'diats $100.27-2 x:$

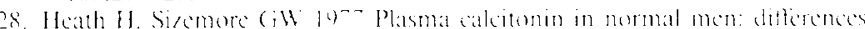
between men and women. I ( lin Lnest $60: 11$ is $11+0$

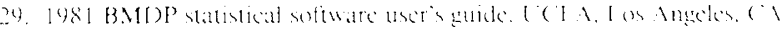

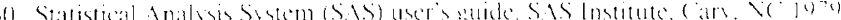

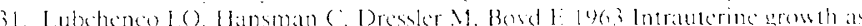

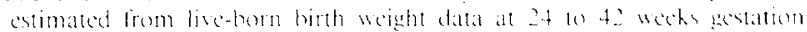
Pediatrics 32,703 sol

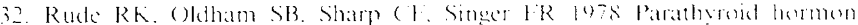

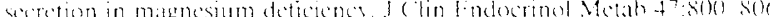

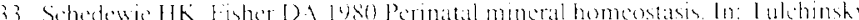

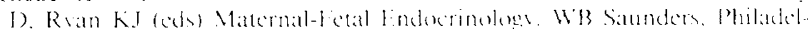

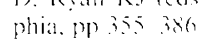

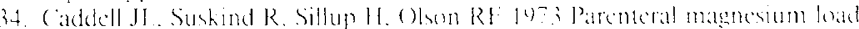

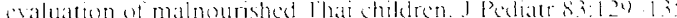

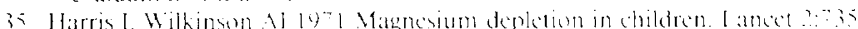
730

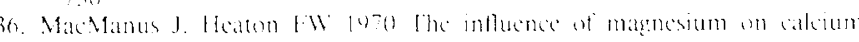

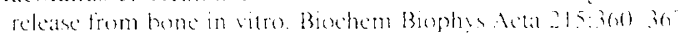

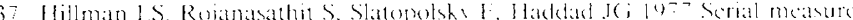

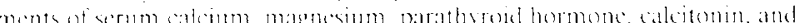

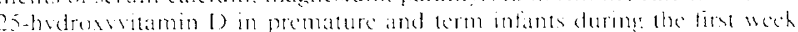
of life. Pediate Res 11:-39 4.4 